medRxiv preprint doi: https://doi.org/10.1101/2021.02.16.21251202; this version posted February 19, 2021. The copyright holder for this preprint (which was not certified by peer review) is the author/funder, who has granted medRxiv a license to display the preprint in It is made available under a CC-BY-NC-ND 4.0 International license .

\title{
The Impact of a Night Travel Ban Policy on Road Traffic Accidents: Interrupted Time Series evidence in Zambia.
}

Key words: Road Traffic Accidents, Motor Vehicle Population, Night Travel Ban, interrupted Time Series Analysis, Zambia

The corresponding author attests that all listed authors meet the authorship criteria and that no others meeting the criteria have been omitted.

Copyright/licence for publication.

The Corresponding Author has the right to grant on behalf of all authors and does grant on behalf of all authors, a worldwide licence to the Publishers and its licensees in perpetuity, in all forms, formats and media (whether known now or created in the future), to i) publish, reproduce, distribute, display and store the Contribution, ii) translate the Contribution into other languages, create adaptations, reprints, include within collections and create summaries, extracts and/or, abstracts of the Contribution, iii) create any other derivative work(s) based on the Contribution, iv) to exploit all subsidiary rights in the Contribution, v) the inclusion of electronic links from the Contribution to third party material whereever it may be located; and, vi) licence any third party to do any or all of the above."

Competing interests declaration.

All authors have completed the ICMJE uniform disclosure form at www.icmje.org/coi_disclosure.pdf and declare: no support from any organisation for the submitted work [or describe if any]; no financial relationships with any organisations that might have an interest in the submitted work in the previous three years [or describe if any]; no other relationships or activities that could appear to have influenced the submitted work.

NOTE: This preprint reports new research that has not been certified by peer review and should not be used to guide clinical practice. 
medRxiv preprint doi: https://doi.org/10.1101/2021.02.16.21251202; this version posted February 19, 2021. The copyright holder for this preprint (which was not certified by peer review) is the author/funder, who has granted medRxiv a license to display the preprint in

It is made available under a CC-BY-NC-ND 4.0 International license .

Details of contributors and the name of the guarantor

Corresponding Author: Kantu Moonga M (0000 00015742 5008), Department of Health Policy and Management, School of Public Health, University of Zambia (UNZA), Lusaka, Zambia, Ministry of health, levy Mwanawasa medical university and teaching hospital, department of psychiatry, Lusaka, Zambia Box 30043, Lusaka, Zambia. Phone: +260977766091. Email:

kantumoonga@yahoo.com. Certificate in planning, monitoring and evaluation, Diploma in pharmacy, Bachelor of Arts degree, MPH.

Second Author: Peter Hangoma head of department, Department of Health Policy and Management, School of Public Health, University of Zambia (UNZA) Box 32379, Lusaka, Zambia, Lusaka, Zambia, Chr. Michelson Institute (CMI), Bergen, Norway, Bergen Centre for Ethics and Priority Setting, University of Bergen, Bergen, Norway. BA -Economics, MA- Economics, PhD,.

Phone: +260955560556. Email: peter.hangoma@unza.com or peter.hangoma@cmi.no

\section{Contributor and guarantor information}

Peter Hangoma: Conceptualization, methodology, formal analysis, supervision.

Kantu Moonga M: Investigation, resources, data curation, writing, visualisation, guarantor.

Correspondence to: kantumoonga@yahoo.com.

Transparency declaration.

This manuscript is an honest, accurate, and transparent account of the study being reported; that no important aspects of the study have been omitted; and that any discrepancies from the study as planned have been explained.

Details of ethical approval.

Approval to carry out this study was given by the university of Zambia biomedical research ethics committee.

Details of funding. The study was not funded. 
medRxiv preprint doi: https://doi.org/10.1101/2021.02.16.21251202; this version posted February 19, 2021. The copyright holder for this preprint (which was not certified by peer review) is the author/funder, who has granted medRxiv a license to display the preprint in

It is made available under a CC-BY-NC-ND 4.0 International license .

\begin{abstract}
The burden of road traffic accidents has been increasing globally with Injuries and deaths from road traffic accidents accounting for a significant share of the global disease burden. This is evident especially in low and middle income countries (LMICs), were these injuries and deaths account for a reasonable share of the disease burden. In Zambia, for example, road traffic accidents are the third leading cause of death after HIV/AIDS and Malaria and more than half of these accidents happen at night. To reverse the growing incidence of road crushes, the government of Zambia put a ban on night travel for public service vehicles in November, 2016. While other countries such as Kenya have implemented similar bans, there is no evidence on the extent to which such a ban may reduce accidents.
\end{abstract}

Objective - to examine the effect of the night travel ban on road traffic accidents in Zambia after the implementation of the night travel ban. The study set out to established whether there was a change in the number of accidents.

Design - the study design was a single group interrupted time series analysis. Administrative data on road traffic accidents in Zambia for the period 1964 to 2018 was used.

Setting - this research was a national study, therefore it encompassed national statistics on road accidents of the entire country of Zambia.

Main outcome measure - The total counts of road traffic accidents in Zambia recorded during the study period 1964 to 2018 .

Results - it was found that the night travel ban reduced the number of road crushes by 1,211 within one year of implementing the intervention. (p value 0.001 , CI -1878.079 to -543.130 ).

Conclusion - the night travel ban may be an effective way of reducing the burden of road traffic injuries in Zambia and other LMICs.

Key words: Road Traffic Accidents, Motor Vehicle Population, Night Travel Ban, interrupted Time Series Analysis, Zambia. 
medRxiv preprint doi: https://doi.org/10.1101/2021.02.16.21251202; this version posted February 19, 2021. The copyright holder for this preprint (which was not certified by peer review) is the author/funder, who has granted medRxiv a license to display the preprint in It is made available under a CC-BY-NC-ND 4.0 International license .

\section{Section 1: What is already known on this topic}

- In Zambia, there is a high number of road traffic accidents that occur during the night compared to the day time (fisa et al, 2019, ikabungo 2015 and patel 1979).

- Interventions have been put in place to reduce the number of accidents but there is no evidence of their effectiveness.

- In light of the lack of evidence of such interventions, the study was carried out to provide evidence to policy makers so that their decisions can be evidence based.

\section{Section 2: what the study adds}

- Our study suggests that the policy proved to be effective in reducing the total number of accidents in Zambia.

- This study provides evidence of the effectiveness of an intervention which in turn provides policy makers with grounds on which to maintain such a policy.

- The study triggers further research on other effects of banning night time travel

Abbreviated running title: Impact of the Night Travel Ban on RTAs in Zambia: Interrupted Time Series. 
medRxiv preprint doi: https://doi.org/10.1101/2021.02.16.21251202; this version posted February 19, 2021. The copyright holder for this preprint (which was not certified by peer review) is the author/funder, who has granted medRxiv a license to display the preprint in It is made available under a CC-BY-NC-ND 4.0 International license .

\section{INTRODUCTION}

\section{Background}

The burden of Road Traffic Accidents (RTAs) has been growing globally, with the rate of mortality increasing by 46\% since 1990 (Lozano et al., 2012). RTAs are responsible for nearly 20 to 50 million injuries each day and killing about 1.35 million people each year [World Health Organisation (WHO) 2018, 2020]. In 2020 it is expected that the number of deaths from accidents will reach 2 million (Mathers and Loncar, 2005, Wegman 2017). Road traffic injuries (RTIs) are ranked as the $8^{\text {th }}$ leading cause of death for all age groups worldwide and it is the leading cause of death for people between 5 29 years. More people die now from RTAs and RTIs than from HIV/AIDS [Centre for Disease control (CDC) 2019]. RTIs account for 83 million Disability Adjusted Life Years (DALYs) globally placing it among the 5 leading causes of DALYs (WHO GHO, 2020). Perhaps more concern is the fact that more than $90 \%$ of the DALYs lost worldwide due to RTIs occurred in low and middle income countries (LMICs) and yet they only account for 54\% of registered global vehicles (WHO, 2015a). This underscores the importance of assessing what policies are needed to reduce RTAs in LMICs. Apart from the large health burden, RTAs also lead to large economic costs in terms of lost productivity and survivors of trauma go on to bear large health costs. A study of 21 countries on the global cost of RTIs estimated that they cost US $\$ 518$ billion (Bachani et al., 2017). RTIs have a huge impact on health and development as they cost governments approximately 3\% of Gross Domestic Product (WHO, 2015).

A number of countries have put in place measures to reduce the burden of RTAs. Measures include stricter rules on speed limits, laws on drunk-driving, seat belt use and improving road infrastructure (WHO 2001). Improving road infrastructure and related aspects such as lighting has shown to be important for road safety at night (Plainis et al., 2006). Others have banned travel in certain places or at certain times for vehicles or users deemed to be high risk. Countries such Kenya and Zambia have instituted night travel bans. Night travel has been associated with increased risk of RTAs in England (Horne, 1995), France (Nabi et al., 2006), Ethiopia (Teferi et al., 2014), China (Zhao, 2010), and Zambia (Ikabongo, 2015), among others. There is a rich literature that has looked at the impact of, or how, different policy measures are associated with RTAs. Staton et al. (2016) found that the most common 
medRxiv preprint doi: https://doi.org/10.1101/2021.02.16.21251202; this version posted February 19, 2021. The copyright holder for this preprint (which was not certified by peer review) is the author/funder, who has granted medRxiv a license to display the preprint in It is made available under a CC-BY-NC-ND 4.0 International license.

intervention evaluated was legislation and it had the best outcomes when combined with strong enforcement initiatives or as part of a multifaceted approach. Speed control was also crucial to crash and injury prevention and road improvement interventions in LMICs settings which should carefully consider how the impact of improvements will affect speed and traffic flow. The study noted that further road traffic injury prevention interventions should be performed in LMICs with patient-centred outcomes in order to guide injury prevention in these complex settings. Grundy et al., (2009) examined the impact of an enforcement of 20 miles per hour (mph) traffic speed zones on RTAs and found a $41.9 \%$ reduction in road casualties. Navoa et al., (2011) evaluated the impact of penalty points system on road traffic injuries in Spain. The penalty point is a system where drivers start with a 12 to 10 point licence and points are gradually removed if certain traffic violations are committed. The study found a significant risk reduction in the post-intervention period with a greater risk reduction among men, moped riders and on urban roads. Porchia et al, 2014 found that visibility aids such as road lighting have the potential to reduce RTAs. There is limited or no evidence on the impact of night travel bans. The closest of evidence is an ex-ante study of the proposed policy to ban express buses from travelling in the early hour in Malaysia (Mohamed et al., 2011). The study concluded that a night travel ban may actually result in undesirable effects. Driving hours would be reduced and working hours would be affected because travellers will rush out of work to travel back home before the ban hours. There would be need for alternative transport for those who travel at night or long journeys and, resting places would be required for drivers. However, the findings were not based on the actual impact of the policy because it was carried out before the pronouncement. Their assessment was a likely impact if such a policy was implemented. In addition, the study used qualitative methods and this does not provide us with a picture of how the number of RTAs change. Other studies suggest that night travel bans may be helpful because night travel carries increased risk. Taylor et al., (2006) notes that a complex link exists between stress, fatigue, sleep, health status and drivers' accident risk. The hormone melatonin which is associated with sleep and is usually suppressed during the day time but released at night (Masters et al., 2014), could be another reason explaining the high number of night time accidents. When released, melatonin causes sedation and is the reason why people feel the need to sleep at night. This can be cause for accidents when caught up on the road. We contribute in filling the gap in the literature examining the impact of 
medRxiv preprint doi: https://doi.org/10.1101/2021.02.16.21251202; this version posted February 19, 2021. The copyright holder for this preprint (which was not certified by peer review) is the author/funder, who has granted medRxiv a license to display the preprint in It is made available under a CC-BY-NC-ND 4.0 International license .

policies to reduce RTAs in general by examining the impact of a night travel ban using a unique opportunity provided by a night travel ban of public transport in Zambia.

\section{Context}

Over the past 50 years, Zambia has witnessed a transformation in the transport system as a result of both political and economic changes. This brought about liberalisation of the transport sector and has led to an increase in the number of vehicles such as minibuses, mid heavy buses and taxis, against limited growth of road infrastructure (Mubanga, 2014). Zambia has made major investments in the road sector. In 2012 the government embarked on a huge program of improving the road infrastructure (Road Development Agency, 2014). Generally, the public service vehicles such as buses remain a principle mode of transport for people and account for most of the traffic related fatalities. Fisa et al (2019) found that in Zambia, there is a reduced incidence of dying if one is using a private vehicle compared to a public vehicle. There are approximately 2,000 annual fatalities from RTAs recorded in Zambia (GRZ, 2015). The capital city, Lusaka, accounts for more than half the total number of nationwide RTAs (RTSA 2017). According to both historical and current studies, most accidents in Zambia occur during the night. In one such study, Patel (1979) found that $40 \%$ of the accidents occurred between 18.00 to 24.00 hours, $39 \%$ occurred between $24: 00$ to $12: 00$ hours and $21 \%$ occurred between 12:00 to 18:00 hours. A 2013 study showed the same trend with 53\% of accidents happening at night and a death rate of 52.27\% (Ikabongo, 2015). Fisa et al (2019) also concluded that driving in the early hours of the day particularly between $1 \mathrm{am}$ to $6 \mathrm{am}$, had an increased incidence of death form traffic crashes. The financial costs that come with RTAs and RTIs in Zambia approaches 3\% of its Gross Domestic Product (Schartz, 2008). RTAs cost the country at least K5 billion per year (Mwamba, 2018). Studies have also shown that injuries have been associated with reduced earned income and lower consumption. Injuries increase consumption in the health sector leading to an increase in health expenditure (Hangoma et al., 2017). This is a constraint on resources which could be channelled to other developmental programs and poverty alleviation. To curb the increasing number of accidents at night, in November 2016, Zambia instituted Statutory Instrument No 76 of 2016, the road traffic (public service vehicles) (restriction on night driving) banning night travel for all public service vehicles between 9pm and 6am (GRZ 2016). 
medRxiv preprint doi: https://doi.org/10.1101/2021.02.16.21251202; this version posted February 19, 2021. The copyright holder for this preprint (which was not certified by peer review) is the author/funder, who has granted medRxiv a license to display the preprint in It is made available under a CC-BY-NC-ND 4.0 International license.

\section{METHODS}

Our study adopted a natural experimental design, particularly a single group Interrupted Time Series Analysis (ITSA) as a method of analysis. This is a time series analysis where the series is divided or interrupted by an intervention into two time periods, the pre-intervention period and the postintervention period. The two-time period are compared to come up with a conclusion on the effects of the intervention. We analysed secondary data on the number of RTAs recorded annually, between 1964 and 2018 from the Zambia police road traffic unit and the road transport and safety agency. The study population included all the RTAs reported and recorded throughout the country in the study period. We also conducted robustness checks to ensure that the data met the prescribed assumptions of ITSA.

\section{Data and Variables}

The main explanatory variable was the intervention: the introduction of the night travel ban in 2016 . We compared the pre-intervention period (1964-2016 prior to the policy pronouncement in November) to the post intervention period (2017 to 2018). The data used from the year 1964 to 2018 gave us 55 time points. Our main outcome was the yearly counts of RTAs in Zambia. These included all accidents reported to have occurred in a year and recorded by the Zambia police service. 55 observations were available for both the pre and post intervention period. Data on RTAs segregated between night and day time accidents in the stated timeframe would have been ideal to create an intervention and control group, but the statistics were not available in this form. We also included other covariates such as motor vehicle population and human population in an alternative specification. It couldn't be included in the main specification because this data was only available from 2005 to 2018 (14 time points). The variable motor vehicle population is the total number of vehicles registered with the road transport and safety agency in a year. Human population included the total number of people recorded in Zambia each year and this data was collected for the study period 1964 to 2018 . The design was aimed at showing whether there was an interruption in the trend after the night travel ban. We noted that history is the most 
medRxiv preprint doi: https://doi.org/10.1101/2021.02.16.21251202; this version posted February 19, 2021. The copyright holder for this preprint (which was not certified by peer review) is the author/funder, who has granted medRxiv a license to display the preprint in

It is made available under a CC-BY-NC-ND 4.0 International license .

common threat to validity with the possibility that some other event could have caused the observed effect in time series. In this regard, we also included dummies in the years Zambia liberalised the transport sector to account for possible structural breaks. We also carried out robustness checks.

\section{Empirical Model.}

To investigate the effect of the night travel ban on the number of RTAs, we began with an interrupted time series model of the form:

$$
R T A_{t}=\beta_{0}+\beta_{1} \text { Trends }+\beta_{2} \text { Night_Ban }+\beta_{3} \text { Night_Ban } \text { B }_{t} \text { Trend }+\mu_{t}
$$

Where $R T A_{t}$ is the number of accidents in year t. Trend is the time trends equal to 1 in the first year, 2 in the second year and so on counting the number of years from 1964 to 2018 . It controls for trends. Night_Ban ${ }_{t}$ is a dummy variable equal to 1 in the period after the night travel ban (post-intervention period) and 0 in the pre-intervention period. It captures the intervention. Night_Ban ${ }_{t} X$ Trend $_{\text {is }}$ ise interaction between the Night Travel Ban and RTAs over time. $\mu_{t}$ is the error term capturing all other factors that may affect RTAs. $\beta_{0}$ represents the starting level of RTAs in $1964 . \beta_{1}$ is the trajectory of RTAs from the starting level in 1964 until the time that the Night Travel Ban was effected in 2016. The parameter $\beta_{2}$ represents the change in the level of RTAs that occurred in the period immediately following the introduction of the Night Travel Ban compared with the counterfactual. The counterfactual in this case is the predicted slope of progression of RTAs through 2017-18, had the intervention not been put in place in 2016. $\beta_{3}$ describes the difference between the pre-intervention slope and the post-intervention slope of RTAs. The parameters of interest in our study are $\beta_{2}$ and $\beta_{3}$. Figure i below shows model (1) graphically: 
medRxiv preprint doi: https://doi.org/10.1101/2021.02.16.21251202; this version posted February 19, 2021. The copyright holder for this preprint (which was not certified by peer review) is the author/funder, who has granted medRxiv a license to display the preprint in

It is made available under a CC-BY-NC-ND 4.0 International license .

Fig i: Single Group Interrupted Time Series of the Impact of RTAs in Zambia.

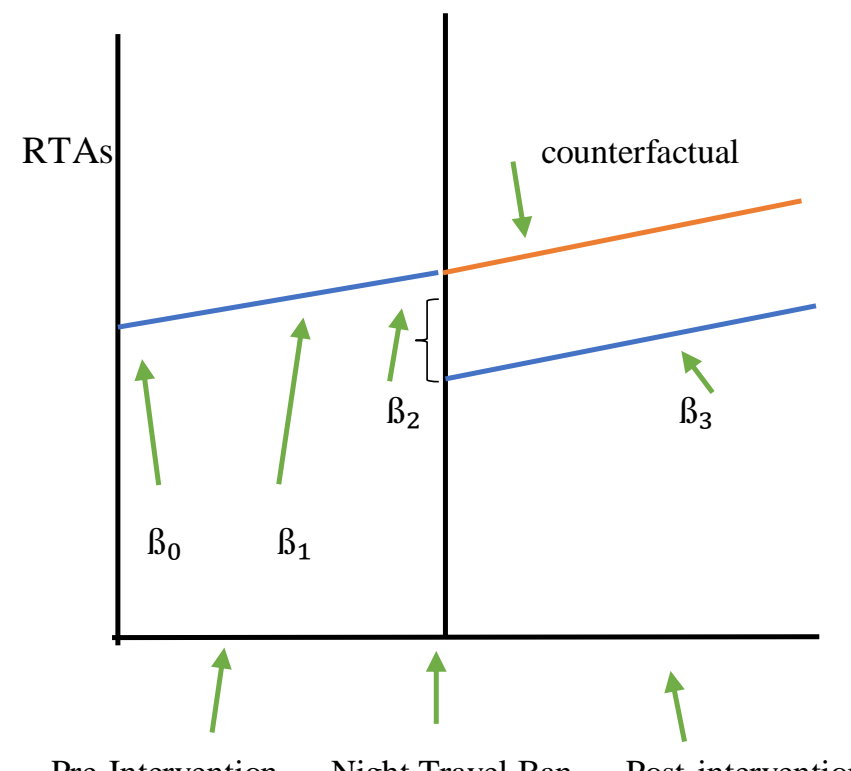

Pre-Intervention Night Travel Ban Post-intervention

Where $\beta_{0}$ is the starting point of RTAs in 1964, $\beta_{1}$ is the change in RTAs over time up until the ban in 2016, $\beta_{2}$ measures the change in the number of RTAs after the ban is implemented while $\beta_{3}$ measures the change of RTAs over time in the period that the ban is in place.

The model was further modified to include a vector $Z_{t}$ that included the number of motor vehicles recorded, human population (number of people) and structural breaks.

$$
R T A_{t}=\beta_{0}+\beta_{1} \text { Trend }+\beta_{2} N i g h t_{-} \text {Ban }_{t}+\beta_{3} N i g h t_{-} \text {Ban }_{t} X \text { Trend }+\beta_{4} Z_{t}+\mu_{t}
$$

Structural breaks were defined as year dummies for most of the periods in the 1990s and early 2000s to account for liberalization of the public transport sectors and other reforms.

Finally, we assessed the model to check for stationarity, normality, homoskedasticity and autocorrelation. This was carried out to make sure that important assumptions about the consistency of these observations were met and that the estimates were the Best Linear Unbiased Estimators (BLUE). This was done to ensure that the study design was robust (Linden A,2016). 
medRxiv preprint doi: https://doi.org/10.1101/2021.02.16.21251202; this version posted February 19, 2021. The copyright holder for this preprint (which was not certified by peer review) is the author/funder, who has granted medRxiv a license to display the preprint in

It is made available under a CC-BY-NC-ND 4.0 International license .

\section{RESULTS}

\section{Descriptive statistics and trends in RTAs}

The number of RTAs, motor vehicle population and human population are described through 1964 to 2018 (Table 1). During the 55 year study period, the average annual number of RTAs that have occurred is 13,745 with a minimum of 3,680 and maximum of 33,672 (standard deviation 8,111 ). These RTAs were further disaggregated into sub-periods to create further understanding on the trend, and these subperiods were randomly created. The average number of RTAs between 1964 and 1973 is 8,120; between 1974 and 1991 is 8,650; between 1992 and 2000 is 12,314 and; between 2000 and 2018 is 22,651 . These results show a steady increase of RTAs over the 55 year period under study. Motor vehicle population had 14 observations and the average number of motor vehicles recorded in the country in the last 14 years is $455,677.8$ with the maximum of 788,168 motor vehicles. 55 observations (19642018) were included for human population and they showed an average population of 8,824,621 with a maximum of $17,600,000$.

Table 1: Summary Statistics

\begin{tabular}{lcllll}
\hline Variable & Observations & Mean & std. Dev & Min & Max \\
\hline Year & 55 & 1991 & 16.02 & 1964 & 2018 \\
RTAs & 55 & $13,745.25$ & $8,111.22$ & 3,680 & 33,672 \\
Motor Vehicle & 14 & $455,677.8$ & 213,565 & 168,638 & 788,168 \\
Population & & & & & \\
Human population & 55 & $8,824,621$ & $3,955,270$ & $3,453,000$ & $17,600,000$ \\
\hline
\end{tabular}

Notes: Summary statistics (Stata 14) included the total number of years, RTAs that occurred, motor vehicles recorded and human population captured in the study period. 
medRxiv preprint doi: https://doi.org/10.1101/2021.02.16.21251202; this version posted February 19, 2021. The copyright holder for this preprint (which was not certified by peer review) is the author/funder, who has granted medRxiv a license to display the preprint in

It is made available under a CC-BY-NC-ND 4.0 International license .

Figure 2 is a graphical depiction of the analysis of RTAs through the study period and it shows an upward trend of RTAs characterised with some fluctuations. The interrupted time series model includes a trend to account for this. The period of 1995 to 2003 showed a more defined fluctuating pattern as the trend followed a sharp upward and downward trend. The fluctuation corresponds to a period of transport liberalization and hence the need to include structural breaks in the model. The dotted vertical line is the intervention depicting the year 2016 when the Night Travel Ban was effected. Visually, the graph showed a reduction in the number of RTAs after the intervention was put in place as evidenced in Table 2. The predicted number of RTAs is plotted against the actual number of RTAs recorded.

Figure 2: RTAs and intervention (2016)

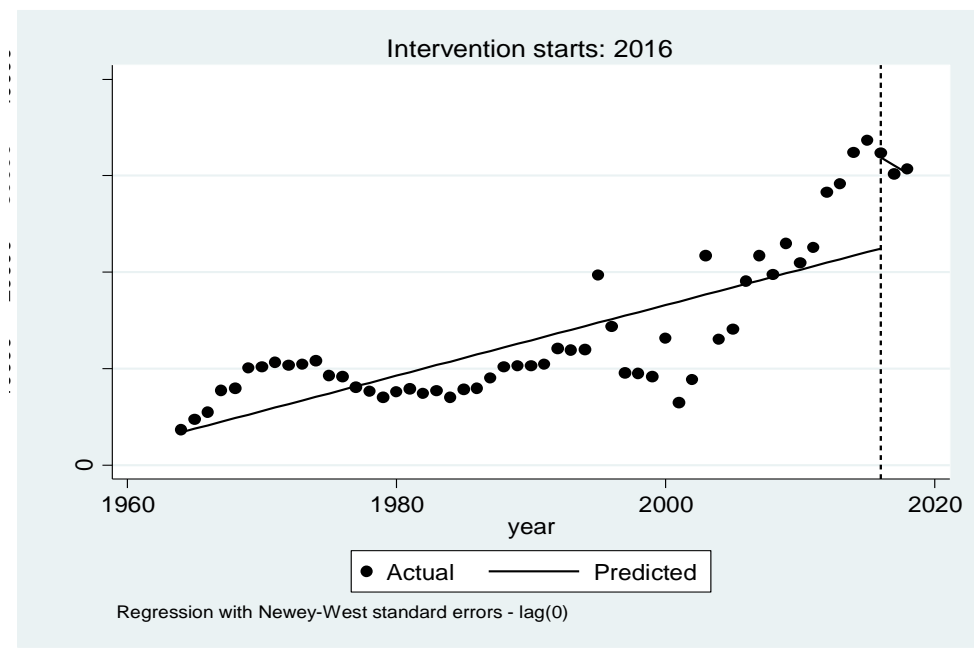

\section{The Effect of the Night Travel Ban on RTAs in Zambia.}

Results show that the night travel ban was associated with a decrease in RTAs by 1.211(Table 2, Row 1). The decrease was highly significant at below the convectional $1 \%$ level. Looking at other parameters of the model, the number of RTAs increased significantly every year prior to the intervention by an average of 366. In the first year of the intervention (2016), the analysis showed an increase of RTAs by approximately 9,454 (p value $0.0001, \mathrm{CI}=5718.971,13189$ ). 
medRxiv preprint doi: https://doi.org/10.1101/2021.02.16.21251202; this version posted February 19, 2021. The copyright holder for this preprint (which was not certified by peer review) is the author/funder, who has granted medRxiv a license to display the preprint in

It is made available under a CC-BY-NC-ND 4.0 International license .

Table 2 : Effect of the night travel ban on road accidents in Zambia

Time Variable: Year, 1964-2018

RTAs

Average Newy-West $\quad T \quad p>|t|$

95\% Confidence

\begin{tabular}{|c|c|c|c|c|c|}
\hline & RTAs & std err & & & interval \\
\hline Post Intervention & -1210.605 & 332.4764 & -3.64 & 0.001 & $-1878.079-(-543.130)$ \\
\hline \multicolumn{6}{|l|}{ Annual Trend $(X t=1)^{e}$} \\
\hline Pre-Intervention $(\mathrm{Xt}=0)^{\mathrm{b}}$ & b 366.1045 & 50.58884 & 7.24 & 0.000 & $264.5432-467.665$ \\
\hline Year of Intervention $^{\mathrm{d}}$ & 9454.287 & 1860.603 & 5.08 & 0.000 & 5718.971-13189 \\
\hline Starting level of RTAs & 3410.776 & 1053.658 & -3.24 & 0.002 & $1295.471-5526.08$ \\
\hline
\end{tabular}

Post-intervention Linear Trend: $\quad 2016$

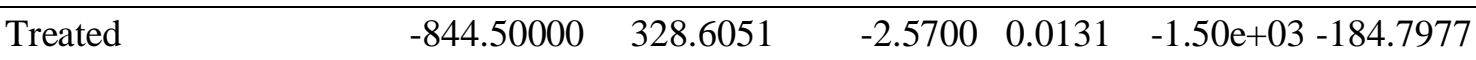

Notes: 1964 to 2018 regression with Newy-West standard errors, Maximum lag 0, number of observations 55. The post intervention linear trend is a confirmatory estimation of the trend after the intervention (lincom post-

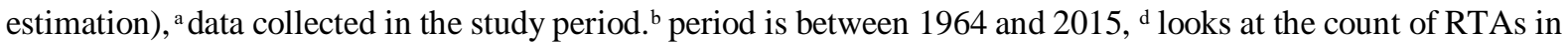
2016, edescribes the trend in 2017 and 2018.

When human population was put into consideration, the analysis showed an increase in RTAs before and in the year of the intervention (1964-2016), then a decrease in RTAs in the post intervention period (2017-2018). Further the analysis showed a reduction in RTAs in the intervention period (2016-2018) when we controlled for motor vehicle population. 
medRxiv preprint doi: https://doi.org/10.1101/2021.02.16.21251202; this version posted February 19, 2021. The copyright holder for this preprint (which was not certified by peer review) is the author/funder, who has granted medRxiv a license to display the preprint in

It is made available under a CC-BY-NC-ND 4.0 International license .

Table 3: Summary of ITSA with motor vehicle and human population.

\begin{tabular}{|c|c|c|c|}
\hline \multirow[t]{2}{*}{ Controls } & Pre- intervention & intervention & post- intervention \\
\hline & $(1964-2015)$ & (2016) & (2017-2018) \\
\hline Non $\quad(1964-2018)$ & increase in RTAs & increase in RTAs & reduction in RTAs \\
\hline \multicolumn{2}{|c|}{ Population (1964-2018) reduction in RTAs } & $* * * *$ & reduction in RTAs \\
\hline Vehicles $\quad(2005-201$ & 3) increase in RTAs & reduction in RTAs & reduction in RTAs \\
\hline
\end{tabular}

**** Results were not significant

Table 4 : Number of RTAs per 100,000 of the population

Year number of RTAs/ 100,000 population

2015

2,172

2016

2,022

2017

1,774

2018

1,742

When the RTAs were analysed per 100, 000 of the population (Table iv), the analysis showed a decreasing trend in the pre-intervention period (2015), intervention period (2016) and post-intervention period (2017-2018). In a time series analysis, a post estimation is carried out to confirm the trend of an analysis. The Lincom Postestimation was employed and it confirmed the reduction of RTAs after the intervention.

\section{Robustness Checks}

We also checked if the data met the assumptions of time series data. The robustness tests for stationarity (pre-estimation) and normality, homoscedasticity, autocorrelation, structural breaks (post-estimation) were carried out. The test for stationarity (Dickey Fuller test) was positive. In the post estimation, the residuals showed a normal distribution (skewness and kurtosis tests). The residuals had characteristics of Heteroscedasticity (8b) and we corrected this by carrying out the analysis using the robust standard 
medRxiv preprint doi: https://doi.org/10.1101/2021.02.16.21251202; this version posted February 19, 2021. The copyright holder for this preprint (which was not certified by peer review) is the author/funder, who has granted medRxiv a license to display the preprint in It is made available under a CC-BY-NC-ND 4.0 International license

error. We also identified autocorrelation (Durbin-Watson statistics, Breush-Godfrey test). This was corrected by transforming the Durbin-Watson statistic. We also checked for structural breaks. The analysis was finally carried out with all these corrections and the results of the analysis still showed a significant reduction in RTAs. We concluded that the estimators were best linear unbiased estimators.

\section{Figure iii: Diagnostics}

\section{Gaussian Distribution- 3a}
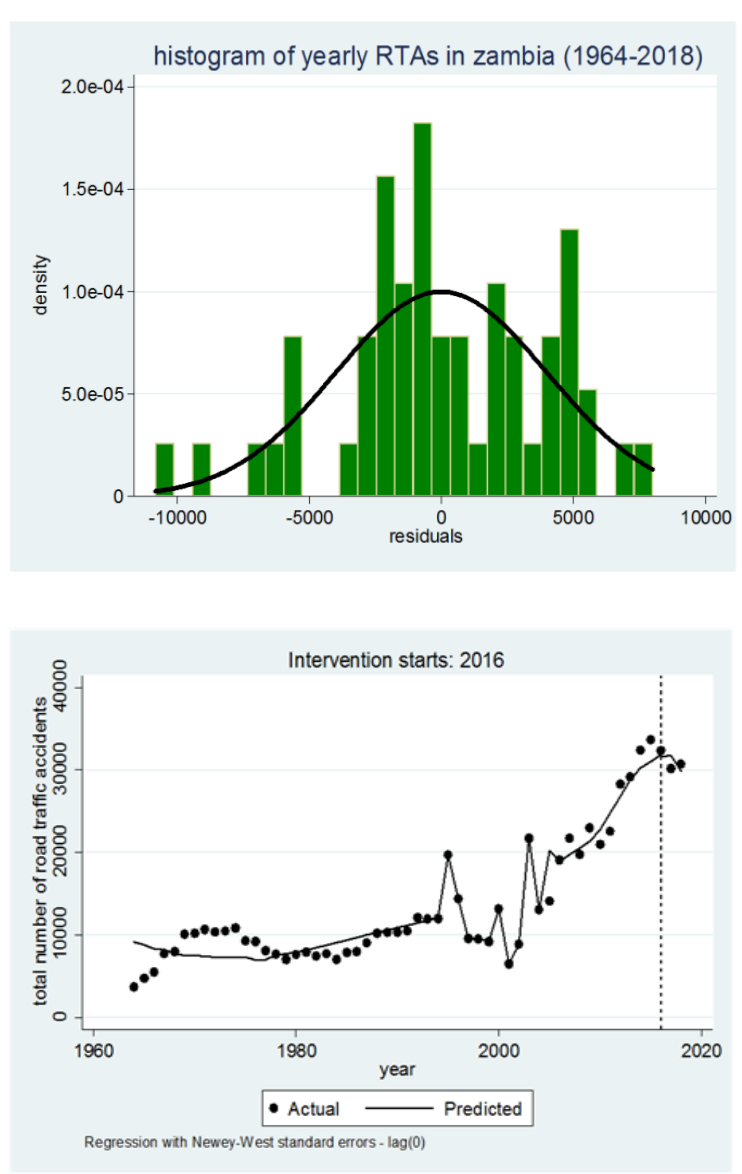

Heteroskedasticity-

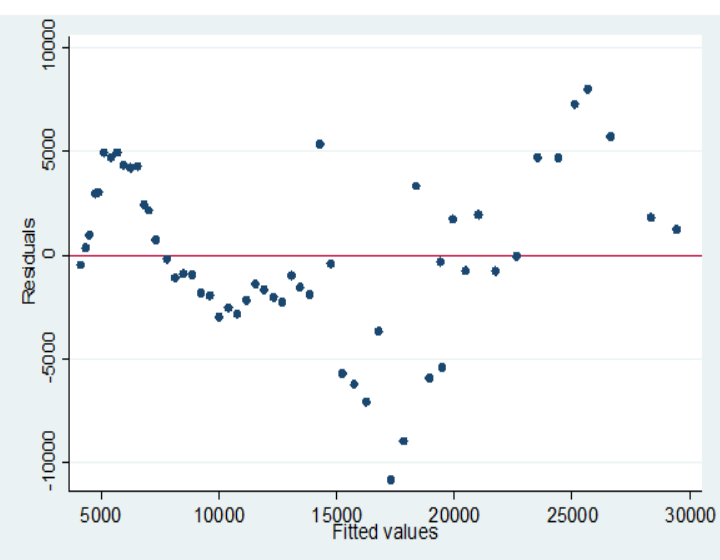

\section{Structural Breaks- 3c}


medRxiv preprint doi: https://doi.org/10.1101/2021.02.16.21251202; this version posted February 19, 2021. The copyright holder for this preprint (which was not certified by peer review) is the author/funder, who has granted medRxiv a license to display the preprint in It is made available under a CC-BY-NC-ND 4.0 International license .

\section{DISCUSSION}

The finding shows a reduction in the number of RTAs in Zambia after implementation of the intervention. We attribute the reduction in RTAs to the Night Travel Ban since it was an intervention that was put in place in that time period. Other interventions may have also contributed to this reduction but this analysis could not take them into account individually. The analysis however shows that RTAs are actually preventable if the correct interventions such as a ban on night travel are put on place. The ban on night travel received a different review in a study carried out in Malaysia prior to the policy pronouncement. Mohammed et al (2011) in his impact assessment analysis concluded that a ban on night time driving would bring about negative effects in the agenda against RTAs. Other studies have shown the effectiveness of improving conditions for people driving at night in order to reduce the number of RTAs. Plainis et al., (2006) also established that corrective measures on night time driving such as increasing lighting reduced RTAs. In Zambia the problem of infrastructure particularly street lighting in rural areas where villagers walk in the main road in the late evening, has contributed to night time accidents involving pedestrians, cyclists and motorists (Schatz, 2008). Night time driving has shown to have more RTAs despite the reduction in the total number of vehicles or the number of miles driven at night compared to day time. Night time driving has certain characteristics. It has fatigued drivers and other factors came into play such as reduced visibility, poor judgement and delayed reaction time. A ban on night time driving would however be more effective in reducing RTAs if a more holistic approach would be considered. Drivers of PSVs should be encouraged to rest and therefore, they and their passengers should have designated resting places if they are caught up in transit during the time of the ban. There is also concern on the economic impact this ban has on the travellers who could be travelling at night to meet productive deadlines. Alternative means of transport should be considered for passengers who need to travel at night such as rail and air transport.

The method of analysis itself (ITSA), shows the ability to demonstrate the change in the trend at a defined point in time resulting from an intervention is a tested method. This method is also cost effective and efficient in evaluating national based interventions which might be too expensive to 
medRxiv preprint doi: https://doi.org/10.1101/2021.02.16.21251202; this version posted February 19, 2021. The copyright holder for this preprint (which was not certified by peer review) is the author/funder, who has granted medRxiv a license to display the preprint in It is made available under a CC-BY-NC-ND 4.0 International license .

evaluate. The study provided a lesson in both the pre and post intervention periods and such methodological study designs have the capacity to impact on risk reduction policy interventions.

\section{CONCLUSION}

We found that the banning of public service vehicles from moving at night lead to a reduction in the total number of road traffic accidents recorded in Zambia. The number of RTAs took an upward trend before the intervention was put in place and later showed a downward trend in the period of the intervention. Evidence of an intervention that is effective has been presented in this study. The analysis had a couple of limitations. Secondary data faces challenges of potential lack of accuracy in recording. There could also have been non-reported or recorded RTAs, especially in rural areas. The study could not take into account other road safety measures that may have contributed to the reduction in RTAs in this period. There was also no specified data on the type of motor vehicles involved in these accidents since the treatment was instituted on the PSVs. The statistics were not available on a quarterly or monthly basis. This would have shown how the trend differs from month to month or quarter to quarter and given a picture of factors that influence such differences.

\section{ABREVIATIONS}

RTAs: Road traffic accidents; PSVs: Public Service Vehicles; ITSA: Interrupted Time Series Analysis, DALYs: Disability Adjusted Life Years Lost; WHO: World Health Organisation; RTIs: Road Traffic Injuries; ZRST: Zambia Road Safety Trust.

\section{COMPETING INTERESTS.}

All authors declare they have no competing interests. 
medRxiv preprint doi: https://doi.org/10.1101/2021.02.16.21251202; this version posted February 19, 2021. The copyright holder for this preprint (which was not certified by peer review) is the author/funder, who has granted medRxiv a license to display the preprint in It is made available under a CC-BY-NC-ND 4.0 International license .

\section{ACKNOWLEDGEMENTS.}

The study benefited from data collected from the Zambia police service and the road transport and safety agency. We thank the faculty at the school of public health at the University of Zambia for their continued advice.

\section{DATA SHARING}

Data collected on this study can be shared on request.

\section{REFERENCES}

1. Bachani M Abdulgafoor, Penden Margie, Gururaj G, Norton Robyn, Hyder A Adnan (2017), Road Traffic Injuries. Injury prevention and environmental health. $3^{\text {rd }}$ Edition. Washington (DC), The international bank for reconstruction and Development/The World Bank; 2017October 27. Chapter 3. doi: 10.1596/978-1-4648-0522-6_ch3.

2. Centre for Disease Control and Prevention (CDC) (2019) Injury Prevention and Control, Global Road Safety, December 18, 2019. Accessed online on $23^{\text {rd }}$ July 2020 http://www.cdc.gov/injury/features/global-roadsafety

3. Fisa Ronald, Nakazwe chola, Michelo Charles, Musonda Patrick (2019), Modelling Deaths Associated with Road Traffic Accidents and other Factors on Great North Road in Zambia between the years 2010 and 2016 using Poisson Models. Open Public Health Journal ISSN: 1874-9445 - Volume 13, 2020.

4. Grundy Chris, Rebecca Steinbach, Phil Edwards, Judith Green, Ben Armstrong, Paul Wilkinson (2009) Effect of 20 Mph Traffic Speed Zones on Road Injuries in London, 1986-2006: controlled interrupted time series analysis. BMJ 2009; 339 doi: https://doi.org/10.1136/bmj.b4469 (Published 11 December 2009). Accessed on 10th may 2018.

5. Government of the Republic of Zambia (GRZ), Report of the Auditor General on Government's measure to reduce road traffic accidents, July 2015. 
medRxiv preprint doi: https://doi.org/10.1101/2021.02.16.21251202; this version posted February 19, 2021. The copyright holder for this preprint (which was not certified by peer review) is the author/funder, who has granted medRxiv a license to display the preprint in It is made available under a CC-BY-NC-ND 4.0 International license .

6. Government of the Republic of Zambia (GRZ) (2016) Statutory Instrument No 76 of 2016, Road Traffic Act 2002 (Act No11 of 2002), The Road Traffic (Public Service Vehicles) (Restriction on Night Driving) Regulations, 2016.

7. Hangoma Peter, Aakvik Arid, Bjarne Robberstad (2017), Health Shocks and Household Welfare in Zambia: An Assessment of Changing Risk. Journal of International Development https://doi.org/10.1002/jid.3337. Accessed on 25th September, 2019.

8. Horne J A, Reyner L A (1995) Sleep related vehicle accidents BMJ 1995; 310 doi: https://doi.org/10.1136/bmj.310.6979.565 (Published 04 March 1995) BMJ 1995;310:565

9. Ikabongo Mwiya (2015), Trends in Road Traffic Deaths among Motorists in Lusaka from 20102013, MPH dissertation, University Of Zambia.

10. Linden Ariel (2016). Challenges to Validity in Single-Group Interrupted Time Series Analysis. Journal of Evaluation in Clinical Practice, International Journal of Public Health Policy and Health Service Research. https://doi.org/10.1111/jep.12638

11. Lozano R, Naghavi M, Foreman K, Lim S, Shibuya K (2012). Global and Regional Mortality from 235 Causes of Death for 20 Age Groups in 1990 to 2010: A Systematic Analysis for the Global Burden of Disease Study 2010. The Lancet 380 (9859): 2095-128.

12. Masters A, Pandi Perumal R S, Seixas A, Girardin J L, McFarlane S 1 Melatonin (2014), Melatonin the Hormone of Darkness: From Sleep Promotion to Ebola Treatment. Brain Disorder Therapy. 2014; 4(1): 1000151. doi:10.4172/2168-975X.1000151. PMCID:PMC4334454 PMID:25705578.

13. Mathers C, Loncar D (2005), Updated projections of global mortality and burden of disease 2002-2030. Methods and results Geneva, WHO 2005.

14. Mohamed N, Mohd-Yusoff MF, Othman I, Zulkipli ZH, Osman MR, Voon WS (2011). Fatigue-related crashes involving express buses in Malaysia: will the proposed policy of banning the early-hour operation reduce fatigue-related crashes and benefit overall road safety? Accid Anal Prev. 2012 Mar; 45 Suppl:45-9. doi: 10.1016/j.aap .2011.09.025. Epub 2011 Oct 11. 
medRxiv preprint doi: https://doi.org/10.1101/2021.02.16.21251202; this version posted February 19, 2021. The copyright holder for this preprint (which was not certified by peer review) is the author/funder, who has granted medRxiv a license to display the preprint in It is made available under a CC-BY-NC-ND 4.0 International license .

15. Mubanga Fredrick (2014), Transformation of the Road Transport System in Zambia. Published online on October 24, 2014 on www.rtsa.org.zm. Accessed on $1^{\text {st }}$ August, 2019.

16. Mwamba Daniel (2018), Improving Road Safety Outcomes in Zambia-Corporate Sector Opportunities. Zambia Road Safety Trust, accessed online on $19^{\text {th }}$ September, 2019 on www.lusakatimes.com.

17. Nabi Hermann, Alice Gueguen, Mireille Chiron, Sylviane Lafort, Marie Zins, Emmanuel Lagrade (2006), Awareness of driving while sleepy and road traffic accidents: prospective study in GAZEL cohort. BMJ, doi:10.1136/bmj.38863.638194.AE (published 23 June 2006).

18. Novoa Ana, Perez Katherine, santamarina-Rubio Elena, Mari-Dell'Olomo Marc, Ferrando Joseph, Peiro Rosana, et al (2011). Impact of the penalty points system on Road Traffic Injuries in Spain: A Time Series Study. Accepted: February 17, 2010. Published Online: September 20,2011

19. Patel N. S, (1979) Traffic Fatalities in Lusaka Zambia. First Published January 1, 1979 Research Article. Medicine, science and law. http://doi.org/10.1177/002580247901900110 Sage journals.

20. Plainis S, I J Murray, I G Palikaris, ( 2006), Road Traffic Casualties: Understanding the NightTime Death Toll, Injury Prevention2006; 12: 125-128 doi:10.1136/ip.2005.01 1056

21. Porchia B R et al (2014). Effectiveness of Two Interventions in Preventing Traffic Accidents: A Systematic Review, Ann Ig 2014; 26: 63-75 doi:10.7416/ai.2014.

22. Road Development Agency [RDA (2014)], Infrastructure sector profile, The link Zambia 8,000 project.

23. Road Transport and Safety Agency (RTSA), Annual Road Traffic Cruashes Report 2017.

24. Schatz Joseph (2008), On the Road in Zambia. World Report| Volume 372, ISSUE 9637, P435436, August 09, 2008. Published: August 09,2008DOI:https://doi.org /10.1016/S0140-6736 (08)61179-4

25. Staton Catherine et al (2016). Road Traffic Injury Prevention Initiatives: A Systematic Review and Meta summary of Effectiveness in Low and Middle Income Countries Plos onedoi:10.1371/journal. Pone .0144971 January 6, 2016. 
medRxiv preprint doi: https://doi.org/10.1101/2021.02.16.21251202; this version posted February 19, 2021. The copyright holder for this preprint (which was not certified by peer review) is the author/funder, who has granted medRxiv a license to display the preprint in It is made available under a CC-BY-NC-ND 4.0 International license .

26. Teferi Abegaz et al (2014) Effects of excessive speeding and falling asleep while driving on crash injury severity in Ethiopia: A generalized ordered logit model analysis Article in Accident Analysis \& Prevention 71:15-21 · October 2014 with 62 Reads DOI:10.1016/j.aap 2014.05.003.

27. Taylor Adrian H, Lisa Dorn (2006). Stress, Fatigue, Health and risk of Road Traffic Accidents among Professional Drivers: the contribution to Physical Inactivity. Vol. 27:371-391 (Volume publication date 21 April 2006) https://doi.org/10.1146/annurev.publhealth. 27.021405.102117.

28. Wegman Fred (2017), The Future of Road Safety, A Worldwide Perspective. International Association of Traffic and Safety Sciences Research, Volume 40 I issue 2, open access.

29. World Health Organisation (WHO) (2001) A 5-year WHO Strategy for Road Traffic Injury Prevention. WHO/NMH/VIP/01.03

30. World Health Organisation (WHO) Global Status Report on Road Safety 2015.

31. World Health Organisation (WHO) 2015a. Global Status Report on Road Safety 2015. Geneva.

32. World Health Organisation (WHO) 2018. Global Status Report on Road Safety 2018. Violence and Injury prevention. http://wwww.who.int/violence injury prevention/safety status/2018/en.

33. World Health Organisation (WHO) (2020), WHO fact sheet on road traffic injuries providing key facts. https://www.who.int/news-room/fact-sheets/detail/road-traffic -injuries. Accessed online on $30^{\text {th }}$ june, 2020 .

34. World Health Organisation (2020) Global Health Observatory (GHO) data disability adjusted life years https://www.who.int/gho/mortality_burden_disease/daly_rates/text/en/

35. Zhao Shangchuan (2010) Rapid Motorization and Traffic Accidents in China. Dalian University of Technology, Dalian, China 116024. 